Lepr Rev (2000) 71, 212-216

\title{
A scholarship project for the children of leprosy patients in Turkey
}

\author{
T. SAYLAN, A. KARADENIZ, N. IYIER, M. SOYDAN \\ \& D. PAMUK \\ Istanbul Leprosy Hospital, Bakirköy 34747, Turkey
}

Accepted for publication 8 March 2000

\begin{abstract}
Summary Most of the leprosy patients in Turkey live in the rural areas of Eastern and South-Eastern Anatolia. Those living in the suburbs of the big cities of the Western parts of the country have come there by immigration. Nearly all patients are very poor; they have no land, or only a small amount of soil for cultivation. The incidence of deformities in our patients is high, excluding them from regular employment and a source of income. In Turkey, it is obligatory to attend primary school, but after that education has to be paid for, and the poor families of leprosy patients find it difficult to continue the education of their children. As the 'Society for the Struggle Against Leprosy', based in the Istanbul Leprosy Hospital at Bakirköy, we have developed a project to enable patients to continue sending their children to school, whilst at the same time asking the mothers to seek advice and guidance on family planning. The outset objective of this project was to enable children and young people, who otherwise have almost no chance of continuing education, to pursue education at secondary, high school and university levels. It was envisaged that in the long term educated children would be able to find a job and provide effective care and support for parents and other members of the family. This paper describes the administrative and other measures adopted and the results of the project from 1995 to 1998, during which a total of 545 children have been supported at an overall cost of US $\$ 107,378$. The scholarship project has so far been remarkably successful in Turkey and it is hoped that it may provide a model for similar approaches in other countries. An unexpected and extremely encouraging finding has been that females now exceed males in this project and are increasing at all levels, including university entrance.
\end{abstract}

\section{Introduction}

Most leprosy patients in Turkey live in the rural areas of Eastern and South-Eastern Anatolia. Most of those living in the suburbs of big cities in the Western parts have come there by immigration. Nearly all of the leprosy patients are very poor. They have either no soil, or only a small amount of barren soil for cultivation.

In a recent study including 527 male and 184 female patients, the incidences of a) eye

Correspondence to: Dr A. Karadeniz (Fax: +90-212-5830086) 
disorders and $b$ ) hand and foot deformities were determined as $75 \cdot 8$ and $73 \cdot 3 \%$, respectively. ${ }^{1}$ Such high rates of disability obviously indicate that patients cannot have a regular job and source of income. Although they are very poor and disabled, nearly all of them, except for those males who are sterile due to erythema nodosum leprosum (ENL), have many children according to the rural traditions. Family planning is not as successful as it should be.

It is hard for the children of poor families living in the rural areas to continue their education after primary school. Boys have few expectations other than being a shepherd or an agricultural worker. Daughters, on the other hand, are taken out of school and forced into marriage when they are believed to have reached 'femininity'. ${ }^{2}$ Poor and disabled leprosy patients with many children request social support, particularly money, to maintain themselves, their families and their medical-social care providers.

As the 'Society for the Struggle Against Leprosy', based in Istanbul Leprosy Hospital, we have developed a project to support leprosy patients under the name of the 'Scholarship Project' to encourage them to keep sending their children to school and to have no other children. This is seen as a progressive and positive step, compared to the unconditional allocation of monthly money.

Thus, the family will have a regular income in a project incorporating a strong element of family planning. Those children and youngsters who normally have almost no chance of an education will continue their schools and obtain a relevant job. In the long term, educated youngsters with a job will provide more effective care and support for their poor and disabled parents and the family will at least have an opportunity to escape from the 'poverty trap'.

\section{Materials and methods}

In this project, patients who came as outpatients to Istanbul Leprosy Hospital, or who were hospitalized, or examined and controlled at their houses in screening trials or who requested help from our social unit by mail, were evaluated.

Each patient was interviewed personally in the hospital or in their area. When these interviews could not be performed, contact was made by telephone or post. ${ }^{3}$

In the above studies, detailed forms were completed, including the medical and social status of the patient together with the age, gender and educational status of their siblings. Later, the following materials were requested from families and their siblings.

1. Scholarship Requirement Form (from the student).

2. Certificate of Educational Status (from the school).

3. A copy of certificate of birth and a photograph.

4. Bank account number (if under 18 years, of a guardian, if over 18 , of the applicant).

5. A certificate indicating that the mother was following some form of family planning (from local government health centre or a government hospital).

As soon as the first five documents were obtained, a financial source for the scholarship was found, or distribution of scholarships began with money obtained from various social activities (teas, meals, fetes/exhibitions and especially the sale of second-hand clothing).

The amount of scholarship money was re-evaluated each year for primary, secondary and high schools and universities according to progress reports and the opportunities available.

Scholarships were sent by bank in two halves, the first being in September for the first 6 months and second in February for the second 6 months of the year. 
At the end of each year the students were requested to write a letter to the Scholarship Unit together with photocopies of their school reports. Our main criterion for continued support was the continuation of education, rather than scholastic or academic success and the passing of examinations, taking into account the adverse social and domestic background of many applicants.

To each of the students who sent the school report and the letter, a book suitable for the age and class of the student was sent together with a letter requesting him/her to read and summarize the book in the summer holiday and send it back to us. The letter emphasized the importance and use of education and family planning and of standing on one's own feet by having a job. The same letter procedure was repeated during the postage of the students' money each September. In this way, a direct connection was maintained by correspondence with each student.

Personal files with a photograph, all documents and letters were collected together and maintained throughout the period of support by our scholarship programme. In the following years students were mostly directed towards 'schools of profession'. Very successful ones were sent to preparation courses and when they passed the university examination they were sent to high schools and universities.

When needed, school materials were provided. Those wishing to get a job by doing shortterm courses (flower arrangement, hair dressing, modelling, typing, computer etc.) were also supported. Particular effort was given to finding jobs for those who had graduated.

\section{Results}

Looking at the distribution of students in our scholarship programme on the map of Turkey, it can be seen that in the top 10 cities, Istanbul comes first and Adana fourth. All the patients in these cities had previously immigrated. All other cities (Van, Elazig, Mus, Malatya, Erzurum, Kahramanmaras, Diyarbakir and Kayseri) are in the Eastern and South-Eastern parts of the country. $^{4,5}$

The scholarship studies were started without having any idea of the likely results and then put on a regular basis. The distributions of students from the last 3 years according to their level of education and gender have been evaluated and are shown in Tables 1-3.

The 445 students shown in Table 2, including 188 females and 257 males, are the relatives of a total of 223 patients. Ninety-two of them had been excluded from the scholarship programme after graduation. Nine of the graduates finished university and 10 students passed university examinations. Eleven students were registered in university preparation courses. In the same year, 1203 books were sent to scholarship students of various years.

Table 1. Scholarships in 1995-1996

\begin{tabular}{lccccc}
\hline Gender & $\begin{array}{c}\text { Primary } \\
\text { school }\end{array}$ & $\begin{array}{c}\text { Secondary } \\
\text { school }\end{array}$ & $\begin{array}{c}\text { High } \\
\text { school }\end{array}$ & University & Total \\
\hline Female & 104 & 33 & 36 & 9 & 182 \\
Male & 108 & 50 & 64 & 24 & 246 \\
Total & 212 & 83 & 100 & 33 & 428 \\
\hline
\end{tabular}


Table 2. Scholarships in 1996-1997

\begin{tabular}{lccccc}
\hline Gender & $\begin{array}{c}\text { Primary } \\
\text { school }\end{array}$ & $\begin{array}{c}\text { Secondary } \\
\text { school }\end{array}$ & $\begin{array}{c}\text { High } \\
\text { school }\end{array}$ & University & Total \\
\hline Female & 104 & 32 & 39 & 13 & 188 \\
Male & 123 & 55 & 60 & 19 & 257 \\
Total & 227 & 87 & 90 & 32 & 445 \\
\hline
\end{tabular}

The 545 students shown in Table 3, including 290 females and 255 males, are the relatives of a total of 273 patients.

\section{COSTS}

The total cost of this project in the years 1995-1998 comes to approximately US $\$ 197,378$, taking into account the constantly fluctuating exchange rate.

\section{Discussion}

An analysis of the Scholarship Project administered by the Social Unit of Istanbul Leprosy Hospital, Society for the Struggle Against Leprosy, has determined that many negative situations have improved over a period of time.

1. Leprosy patients with the motivation of having a constant income did their best to maintain their children's education and showed care in providing the necessary documents, corresponding regularly and even checking the attendance of their children in school in order to maintain the scholarship, in contrast to a previous lack of interest in the subject of education.

2. Patients who had answered the questions 'Why don't you use methods of family planning; why do you have so many children?' now send certificates of family planning on a regular basis.

3. The decrease in the number of students attending secondary schools and high schools shows that while families still find primary education relevant, they continue to take their children out of school for working in the fields. In the primary school, the number of boys is equal to the number of girls, as it is obligatory to attend primary school. The number of boys attending secondary and high schools and universities increases in the rural areas

Table 3. Scholarships in 1997-1998

\begin{tabular}{lccccc}
\hline Gender & $\begin{array}{c}\text { Primary } \\
\text { school }\end{array}$ & $\begin{array}{c}\text { Secondary } \\
\text { school }\end{array}$ & $\begin{array}{c}\text { High } \\
\text { school }\end{array}$ & University & Total \\
\hline Female & 131 & 70 & 67 & 22 & 290 \\
Male & 130 & 63 & 47 & 15 & 255 \\
Total & 261 & 133 & 114 & 37 & 545 \\
\hline
\end{tabular}


just as in Turkey in general. However, patients continue to send their children to school without considering any gender difference to get the 'scholarship'.

4. Although a few parents still take their children out of school to work in the fields, this is exceptional. In general, the level of interest in education and attendance rates at school has been excellent. It is particularly encouraging to note (Table 3) that females now exceed males in this project; they are increasing at all levels including university - an unexpected, but extremely encouraging development.

In conclusion the Scholarship Project: a) aims to provide financial support to poor and mostly disabled leprosy patients, b) obliges patients with large families to have no more children and voluntarily to adopt family planning, c) addresses the inequality of gender in education in rural areas, d) proves that the healthy children of a group of patients of ten excluded from the society can be educated like other people and may excel in their attainments, compared to others living in the same socio-economic conditions, e) encourages leprosy patients to have their children educated, leading to a career, honour and greater confidence and f) improves medical control and therapy by providing close contact between the patient and the health services.

\section{References}

${ }^{1}$ Cakiner T, Yulsel A, Senal-Egit A, Cagn A, Karacorlu M, Kultur A. The extent of leprosy-related disabilities in Istanbul Leprosy Hospital, Turkey. Lepr Rev, 1997; 68: 43-49.

2 Situation of the World's Children. UNICEF Publications, 1988.

3 Soydan M. A rural development model. Social activities in diseases with a social dimension. Istanbul Leprosy Hospital publication. Social Services Unit, Bakirköy, Turkey, 1993.

4 Aytekin AH, Saylan T. Close-contact surveys and mass screening studies for leprosy in Turkey. Lepr Rev, 1988; 59: 225-229.

5 Aytekin AH, Saylan T. Leprosy in Turkey. Lepr Rev, 1988; 59: 231-234. 